\title{
PENGARUH LEVERAGE, PROFITABILITY, UKURAN PERUSAHAAN DAN PROPORSI KEPEMILIKAN INSTITUSIONAL TERHADAP TAX AVOIDANCE
}

\author{
Vidiyanna Rizal Putri' ${ }^{1}$ Bella Irwasyah Putra ${ }^{2}$ \\ ${ }^{1}$ STIE Indonesia Banking School, Jl. Kemang Raya 35 Jakarta \\ vidiputri@ibs.ac.id \\ ${ }^{2}$ STIE Indonesia Banking School, Jl. Kemang Raya 35 Jakarta \\ Email: Bella.irwasyah@hotmail.com
}

\begin{abstract}
Tax avoidance is a tax savings actions that are still in the realm of tax law (lawful fashion). Leverage (DER), profitability (ROA), firms size, and the proportion of institutional ownership are used as independent variables were estimated impact on tax avoidance as the dependent variable and proxied through Cash Effective Tax Rate (CETR). This research was conducted on manufacturing firms in Indonesia Stock Exchange (IDX) 2013-2015. Data obtained by accessing the Indonesia Stock Exchange's website. The samples in this study used nonprobability sampling method with purposive sampling technique in order to get a sample size of 34 companies and the number of observations is 80 times. Data in this study were analyzed with multiple linear analysis techniques. The results of this study indicate that the proportion of institutional ownership and firms size has a positive effect on tax avoidance, while the negative effect of leverage and profitabiliy on tax avoidance.
\end{abstract}

Keywords: tax avoidance, cash effective tax rate, leverage (DER), profitability (ROA), firms size, and the proportion of institutional ownership.

\begin{abstract}
Abstraksi
Penelitian ini bertujuan untuk menganalisis pengaruh hutang, profit, ukuran perusahaan, dan proporsi kepemilikan institutional terhadap tax avoidance. Objek penelitian ini merupakan perusahaan manufaktur sektor industri barang konsumsi yang terdaftar di Bursa Efek Indonesia pada periode tahun 2013 sampai dengan 2015. Pengambilan sampel menggunakan nonprobability sampling dengan teknik purpose sampling. Jumlah sampel sebanyak 34 perusahaan. Analisis data menggunakan teknik multiple linear analysis. Hasil analisis menunjukkan bahwa leverage dan profitability memiliki pengaruh negatif dan signifikan terhadap tax avoidance karena perusahaan-perusahaan manufaktur sub sektor konsumsi merupakan perusahaan yang operasionalnya banyak dibiayai oleh hutang. Ukuran perusahaan dan proporsi kepemilikan berpengaruh positif dan signifikan. Semakin besar ukuran perusahaan maka cash effective tax rate perusahaan akan semakin besar yang mengindikasikan tingkat penghindaran pajak yang semakin rendah.
\end{abstract}

Keywords: leverage, profitability, ukuran perusahaan, kepemilikan institusional, tax avoidance 


\section{Pendahuluan}

Pajak mempunyai peranan yang sangat penting dalam kehidupan bernegara, khususnya dalam pelaksanaan pembangunan karena pajak merupakan sumber pendapatan negara terbesar yang digunakan untuk membiayai semua pengeluaran termasuk pengeluaran pembangunan. Definisi pajak menurut Undang-Undang Nomor 16 tahun 2009 tentang Ketentuan Umum dan Tata Cara Perpajakan pada Pasal 1 ayat 1 merupakan kontribusi wajib kepada negara yang terutang oleh orang pribadi atau badan yang bersifat memaksa berdasarkan undang-undang, dengan tidak mendapatkan imbalan secara langsung dan digunakan untuk keperluan negara (Diantari dan Ulupui, 2016).

Pajak merupakan sumber pendapatan negara yang terbesar, yaitu $1.489,3$ triliun rupiah $(84,5$ persen) dari total pendapatan negara 1.761,6 triliun rupiah dalam APBN-P 2015 (www.kemenkeu.go.id). Penerimaan tersebut antara lain digunakan untuk meningkatkan pendidikan dan kesejahteraan rakyat, membangun infrastruktur pendorong pertumbuhan ekonomi, mendukung ketahanan dan keamanan, serta untuk pembangunan di daerah (RAPBN 2014).

Fenomena perbedaan kepentingan antara wajib pajak dengan pemerintah dan ratarata rasio pajak yang belum mencapai target dapat mengindikasikan adanya aktivitas penghindaran pajak yang cukup besar, sehingga penerimaan pajak negara Indonesia masih belum optimal. Selain dituntut untuk membayar pajak sebagai kewajiban, perusahaan-perusahaan go public di Indonesia juga diharuskan untuk menerapkan corporate governance. Tata kelola perusahaan yang menjelaskan hubungan antara pemilik dan manajer perusahaan dalam menentukan arah kinerja perusahaan disebut corporate governance (Annisa dan Kurniasih, 2012).

Berdasarkan penelitian Diantari dan Ulupui (2016) mengatakan bahwa perbedaan kepentingan antara fiskus dan perusahaan berdasarkan teori keagenan akan menimbulkan ketidakpatuhan yang dilakukan oleh wajib pajak atau pihak manajemen perusahaan yang berdampak pada perusahaan untuk melakukan tax avoidance. Jacob (2014) mendefinisikan tax avoidance sebagai suatu tindakan untuk melakukan pengurangan atau meminimalkan kewajiban pajak dengan hati-hati mengatur sedemikian rupa untuk mengambil keuntungan dari celah-celah dalam ketentuan pajak, seperti pengenaan pajak melalui transaksi yang bukan merupakan obyek pajak. Sebagai contoh, perusahaan yang mengubah tunjangan karyawan dalam bentuk uang menjadi pemberian natura, karena natura bukan merupakan obyek pajak dalam PPh Pasal 21.

Dalam praktik tax avoidance, wajib pajak tidak secara jelas melanggar undang-undang atau menafsirkan undang-undang namun tidak sesuai dengan maksud dan tujuan undangundang. Praktik tax avoidance yang dilakukan oleh manajemen suatu perusahaan sematamata untuk meminimalisasi kewajiban pajak yang dianggap legal, membuat perusahaan memiliki kecenderungan untuk melakukan berbagai cara untuk mengurangi beban pajaknya. Oleh karena itu persoalan tax avoidance merupakan persoalan yang unik dan rumit karena di satu sisi tax avoidance tidak melanggar hukum, tapi disisi lain tax avoidance tidak diinginkan oleh pemerintah.

Leverage (struktur utang) merupakan rasio yang menunjukkan besarnya utang yang dimiliki oleh perusahaan untuk membiayai aktivitas operasinya. Penambahan jumlah utang akan mengakibatkan munculnya beban bunga yang harus dibayar oleh perusahaan. Komponen beban bunga akan mengurangi laba sebelum kena pajak perusahaan, sehingga beban pajak yang harus dibayar perusahaan akan menjadi berkurang (Adelina, 2012).

Return on assets (ROA) merupakan salah satu pendekatan yang dapat mencerminkan profitabilitas suatu perusahaan. Pendekatan ROA menunjukkan bahwa besarnya laba yang diperoleh perusahaan dengan menggunakan total aset yang dimilikinya. ROA juga memperhitungkan kemampuan perusahaan dalam menghasilkan laba yang terlepas 
dari pendanaan. Semakin tinggi rasio ini, semakin baik performa perusahaan dengan menggunakan aset dalam memperoleh laba bersih. Tingkat profitabilitas perusahaan berpengaruh negatif dengan tarif pajak efektif karena semakin efisien perusahaan, maka perusahaan akan membayar pajak yang lebih sedikit sehingga tarif pajak efektif perusahaan tersebut menjadi lebih rendah (Derazhid dan Zhang, 2003).

Ukuran Perusahaan menunjukkan kemampuan perusahaan dengan tindakan pengembalian keputusan perpajakannya. Ukuran perusahaan menunjukkan kestabilan dan kemampuan perusahaan untuk melakukan aktivitas ekonominya. Semakin besar ukuran perusahaan maka semakin menjadi pusat perhatian dari pemerintah dan akan menimbulkan kecenderungan untuk berlaku patuh (compliances) atau menghindari pajak (tax avoidance) (Kurniasih \& Sari, 2013).

OECD (2004) menyatakan prinsip utama untuk tata kelola perusahaan yang baik harus didasarkan pada keterbukaan dan transparansi. Bahkan, kerangka tata kelola perusahaan harus memastikan bahwa pengungkapan yang tepat waktu dan akurat dibuat pada semua hal yang material mengenai korporasi, termasuk situasi keuangan, kinerja, kepemelikan, dan tata kelola perusahaan. Selain itu, struktur kepemilikan juga dapat digunakan untuk mengurangi konflik keagenan. Kepemilikan institsuional akan mendorong peningkatan efektivitas monitoring kinerja manajemen. Investor institusional merupakan pemegang saham yang berbentuk institusi, seperti Perusahaan Asuransi, Bank atau Institusi lain. Kepemilikan saham yang terkonsentrasi oleh institusional investor akan lebih mengoptimalkan efektivitas pengawasan aktivitas manajemen karena besarnya dana yang ditanamkan oleh mereka, Haryono (2005).

\section{Tinjauan Pustaka}

\section{Teori Agensi}

Konsep agency theory menurut Anthony dan Govindarajan dalam Siagian (2011:10) adalah hubungan atau kontak antara principal dan agent. Principal mempekerjakan agent untuk melakukan tugas untuk kepentingan principal, termasuk pendelegasian otorisasi pengambilan keputusan dari principal kepada agent. Pada perusahaan yang modalnya terdiri atas saham, pemegang saham bertindak sebagai principal, dan CEO (Chief Executive Officer) sebagai agent mereka. Pemegang saham mempekerjakan CEO untuk bertindak sesusai dengan kepentingan principal.

Agency conflict sendiri terbagi menjadi dua bentuk, yaitu : (1) agency conflict antara pemegang saham dan manajer. Penyebab konflik antara manajer dengan pemegang saham diantaranya adalah pembuatan keputusan yang berkaitan dengan aktivitas pencarian dana dan pembuatan keputusan yang berkaitan dengan bagaimana dana yang diperoleh tersebut diinvestasikan. (2) agency conflict antara pemegang saham dan kreditor (Kirana, 2007).

Asimetri informasi dan konflik kepentingan yang terjadi antara principal dan agent mendorong agent untuk menyajikan informasi yang tidak sebenarnya kepada principal, terutama jika informasi tersebut berkaitan dengan pengukuran kinerja agent. Hal ini memacu agent untuk memikirkan bagaimana angka akuntansi tersebut dapat digunakan sebagai sarana untuk memaksimalkan kepentingannya. Salah satu bentuk tindakan agent tersebut adalah yang disebut sebagai manajemen laba. (Widyaningdyah, 2001).

\section{Tax Avoidance}

Menurut Lyons "Tax avoidance is a term used to describe the legal arrangements of tax payer's affairs so as to reduce his tax liability". Penghindaran pajak adalah rekayasa 'tax affairs' yang masih tetap berada di dalam bingkai ketentuan perpajakan (lawful). Wajib Pajak melakukan penghindaran pajak dengan mentaati aturan yang berlaku yang sifatnya legal dan diperbolehkan oleh peraturan perundang-undangan perpajakan. Pemerintah tidak bisa melakukan penuntutan secara 
hukum, meskipunpraktik penghindaran pajak ini akan mempengaruhi penerimaan negara dari sektor pajak. (Ngadiman dan Puspitasari ,2014).

\section{Leverage}

Leverage adalah salah satu rasio keuangan yang menggambarkan hubungan antara hutang perusahaan terhadap modal maupun asset perusahaan. Rasio leverage menggambarkan sumber dana operasi yang digunakan oleh perusahaan. Rasio leverage juga menunjukkan risiko yang dihadapi perusahaan. Menurut Irfan Fahmi (2012:62) rasio leverage adalah mengukur seberapa besar perusahaan dibiayai dengan hutang. Rasio ini dapat melihat sejauh mana perusahaan dibiayai oleh hutang atau pihak luar dengan kemampuan perusahaan yang digambarkan oleh modal.

\section{Profitability}

Menurut Standar Akuntansi Keuangan (2009), indikator kinereja perusahaan terutama profitabilias diperlukan untuk menilai perubahan potensial sumber daya ekonomi yang mungkin dikendalikan di masa depan. Prospek yang bagus akan menarik minat investor untuk berinvestasi dalam suatu perusahaan sehingga diperlukan pengungkapan yang lebih luas pada laporan tahunan perusahaan. Rasio profitabilitas menjadi bentuk penilaian terhadap kinerja manajemen dalam mengelola kekayaan perusahan yang ditunjukkan oleh laba yang dihasilkan. Hal ini berarti bahwa rasio profitabilitas menunjukkan kemampuan perusahaan dalam menghasilkan laba dengan menggunakan aset maupun modal perusahan (Sjahrial dan Purba, 2011:40).

\section{Ukuran Perusahaan}

Teori keagenan menyatakan bahwa perusahaan besar memiliki biaya keagenan yang lebih besar daripada perusahaan kecil, Jensesn dan Meckling (1976). Menurut Siregar dan Utama (2005), semakin besar ukuran perusahaan biasanya informasi yang tersedia untuk investor dalam mengambil keputusan sehubungan dengan investasi saham yang ditanamkan dalam perusahaan tersebut semakin banyak. Oleh karena itu, kualitas laporan keuangan harus reliabel, terbebas dari manajemen laba karena dapat mengaburkan informasi yang tersedia. Terutama yang berkaitan dengan minimalisasi laba untuk meminimalkan pendapatan kena pajak, sehingga pembayaran pajak juga kecil.

\section{Proporsi Kepemilikan Institusional}

Kepemilikan institusional adalah kepemilikan saham perusahaan oleh institusi keuangan seperti perusahaan asuransi, bank , dana pensiun,dan investment banking (Veronica dan Utama, 2005). Adanya kepemilikan oleh investor institusional seperti perusahaan efek, perusahaan asuransi, perbankan, perusahaan investasi, dana pensiun, dan kepemilikan institusi lain akan mendorong peningkatan pengawasan yang lebih optimal terhadap kinerja manajemen, karena kepemilikan saham mewakili sumber kekuasaan (source of power) yang dapat digunakan untuk mendukung atau sebaliknya terhadap keberadaan manajemen (Kartikawati, 2009).

\section{Pengembangan Hipotesis}

a. Pengaruh Leverage terhadapa Tax Avoidance

Leverage adalah salah satu rasio keuanganyangmenggambarkanhubungan antara hutang perusahaan terhadap modal maupun aset perusahaan. Rasio leverage menggambarkan sumber dana operasi yang digunakan oleh perusahaan. Rasio leverage juga menunjukan risiko yang dihadapi perusahaan (Wirna Yola Gusti, 2013). Cahyono, Andini, dan Raharjo (2016) membuktikan bahwa Leverage (DER) tidak berpengaruh terhadap Tax Avoidance. Kurniasih dan Sari (2013: 65) melakukan penelitian mengenai pengaruh leverage terhadap penghindaran pajak. Hasilnya, leverage tidak memiliki pengaruh yang signifikan terhadap penghindaran pajak. 
H1: Leverage berpengaruh negatif terhadap Tax Avoidance

b. Pengaruh Profitability terhadap Tax Avoidance

Profitabillitas adalah suatu indikator kinerja manajemen dalam mengelola kekayaan perusahaan yang ditujukan oleh laba yang dihasilkan, Sudarmadji dan Sularto (2007). Profitabilitas dalam bentuk bersih dialokasikan untuk mensejahterakan pemegang saham dalam bentuk membayar dividen dan laba ditahan, Nuringsih (2010). Apabila rasio profitabilitas tinggi, berarti menunjukkan adanya efisiensi yang dilakukan oleh pihak manajemen. Laba yang meningkat mengakibatkan profitabilitas perusahaan juga meningkat.

H2: Profitability berpengaruh positif terhadap Tax Avoidance

\section{c. Pengaruh Ukuran Perusahaan terhadap Tax Avoidance \\ Pada dasarnya perusahaan yang} besar selalu memperoleh laba yang besar. Laba yang besar akan menarik perhatian pemerintah untuk dikenakan pjajak yang sesuai, Asfiyati (2012). Perusahaan yang besar akan semakin kompleks transaksinya sehingga akan semakin memanfaatkan celah untuk melakukan tindakan tax avoidance (Rego ,2003). Sabli dan Md Noor (2012) membuktikan bahwa ukuran perusahaan berpengaruh negatif tidak signifikan terhadap tax planning, sedangkan hasil penelitian
Pohan (2009) membuktikan bahwa size perusahaan berpengaruh positif terhadap tax avoidance.

H3: Ukuran Perusahaan berpengaruh positif terhadap Tax Avoidance

d. Pengaruh Proporsi Kepemilikan Institusional terhadap Tax Avoidance Kepemilikan Institusional merupakan salah satu yang juga dapat digunakan untuk mengurangi agency conflict. Pohan (2009) menemukan bukti bahwa kepemilikan institusional berpengaruh negatif terhadap tindakan tax avoidance. Khurana dan Moser (2009) mengungkapkan bahwa perusahaan dengan kepemilikan institusi yanng besar dikaitkan dengan tingkat agresivitas pajak yang dilakukan oleh perusahaan. Hasil penelitiannya membutkikan bahwa kepemilikan institusional berpengaruh signifikan positif terhadap tax avoidance.

H4: Proporsi Kepemilikan Institusional berpengaruh positif terhadap Tax Avoidance

\section{Metodologi Penelitian}

Objek penelitian ini merupakan perusahaan manufaktur sektor industri barang konsumsi yang terdaftar di Bursa Efek Indonesia pada periode tahun 2013 sampai dengan 2015.Tabel 1 menunjukkan jumlah observasi yang digunakan dalam penelitian berdasarkan pada kriteria yang telah ditetapkan (purposive sampling) adalah sebanyak 80 observasi.

Tabel 1. Kriteria Pemilihan Sampel

\begin{tabular}{|c|c|}
\hline Kriteria & Jumlah \\
\hline $\begin{array}{l}\text { Jumlah perusahaan manufaktur industri barang konsumsi yang listed di } \\
\text { Bursa Efek Indonesia dari tahun 2013-2015 }\end{array}$ & 42 \\
\hline $\begin{array}{l}\text { Jumlah perusahaan dengan data tidak memenuhi kriteria, seperti tidak } \\
\text { listing pada tahun } 2013-2015 \text {, perusahaan yang di delisting, tidak } \\
\text { menyajikan mata uang dalam bentuk rupiah }\end{array}$ & (5) \\
\hline $\begin{array}{l}\text { Jumlah perusahaaan yang memiliki data tidak lengkap selama periode } \\
2013-2015\end{array}$ & (3) \\
\hline
\end{tabular}




\begin{tabular}{|c|c|}
\hline Kriteria & Jumlah \\
\hline Jumlah perusahaan yang menjadi sampel penelitian & 34 \\
\hline Total Observasi (3 tahun) & 102 \\
\hline Outliers & $(22)$ \\
\hline Total Observasi dalam penelitian & 80 \\
\hline
\end{tabular}

Sumber: www.idx.co.id, data diolah oleh penulis;2017

\section{Operasionalisasi Variabel Penelitian}

Dalam penelitian ini, tax avoidance diukur dengan cash effective tax rate, leverage diukur dengan debt to equity ratio, profitability diukur dengan return on assets, ukuran perusahaan diukur dengan logaritma natural total aset, dan proporsi kepemilikan institusional diukur dengan indikator presentase jumlah saham yang dimiliki institusi dari seluruh modal saham yang beredar.

\section{Model Penelitian}

Model yang dilakukan dalam penelitian ini adalah :

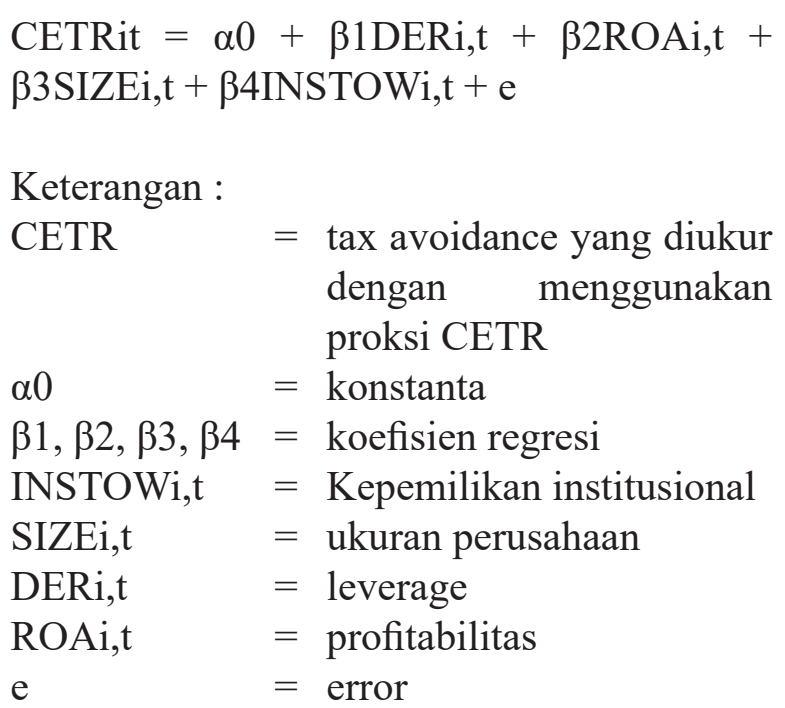

\section{Hasil Penelitian dan Pembahasan}

\section{Statistik Deskriptif}

Tabel 2 Statistik Deskriptif

\begin{tabular}{lccccc}
\hline & CETR & DER & ROA & SIZE & INSTOW \\
\hline Mean & 0.267585 & 0.434670 & 0.175615 & 22.90880 & 0.008783 \\
Median & 0.268915 & 0.422852 & 0.130405 & 25.32965 & 0.005019 \\
Maximum & 0.672151 & 1.248573 & 0.884856 & 30.24816 & 0.061477 \\
Minimum & -0.214834 & 0.157710 & -0.155974 & 12.99695 & -0.009630 \\
Std. Dev. & 0.139033 & 0.199921 & 0.174283 & 5.567071 & 0.010975 \\
Observations & 80 & 80 & 80 & 80 & 80 \\
\hline
\end{tabular}

Sumber: hasil output program Eviews 9.0, 2017

Tabel 2. menunjukkan bahwa tax avoidance memiliki nilai rata-rata (mean) sebesar 0,267585 dan nilai median sebesar 0,268915. Hasil ini menunjukkan bahwa nilai rata-rata (mean) lebih rendah daripada nilai median yang berarti bahwa rata-rata perusahaan manufaktur sub sektor konsumsi cenderung melakukan penghindaran pajak (tax avoidance) ) yang dilihat cash effective tax rate. Mean DER adalah sebesar 0,434670 dengan median sebesar 0.422852 . Hasil ini menunjukkan bahwa nilai rata-rata (mean) lebih tinggi dibandingkan median yang berarti bahwa rata-rata perusahaan manufaktur sub sektor konsumsi memiliki nilai debt ratio yang besar, yang mengindikasikan bahwa bank-bank tersebut memiliki hutang yang besar untuk menjalankan operasionalnya sehingga perusahaan mengalami tekanan dari pihak eksternal yang tinggi. Mean ROA adalah sebesar 0,175615 dengan median sebesar 0,130405. Hasil ini menunjukkan bahwa nilai rata-rata (mean) lebih tinggi dibandingkan median yang berarti bahwa rata-rata perusahaan manufaktur sub sektor konsumsi memiliki nilai return on assets 
yang besar, yang mengindikasikan bahwa perusahan manufaktur sub sektor konsumsi tersebut memiliki target keuangan yang besar. Mean SIZE adalah sebesar 22,90880 dengan nilai median sebesar 25,32965. Hasil ini menunjukkan bahwa nilai rata-rata (mean) lebih rendah daripada nilai median yang berarti bahwa rata-rata perusahaan manufaktur sub sektor konsumsi mempunyai ukuran perusahaan yang relatif rendah. Mean INSTOW adalah sebesar 0,008783 dengan nilai median sebesar 0,005019. Hasil ini menunjukkan bahwa nilai rata-rata (mean) lebih tinggi daripada nilai median yang berarti bahwa rata-rata perusahaan manufaktur sub sektor konsumsi memiliki jumlah kepemilikan saham institusional yang tinggi.

\section{Asumsi Klasik dan Analisis Data Panel}

Berdasarkan hasil uji asumsi klasik dapat disimpulkan bahwa model penelitian memenuhi syarat uji normalitas dan asumsi klasik (multikolonieritas, autokorelasi, dan heteroskedastisitas). Teknik regresi data panel digunakan untuk mengestimasi model common, fixed dan random effect. Dalam penelitian ini, setelah melakukan uji chow diestimasi dengan teknik fixed effect sehingga dilanjutkan dengan uji hausman, penelitian ini menggunakan teknik random effect.

\section{Pembahasan Hipotesis}

Tabel 3. Hasil Regresi Data Panel (Random Effect)

\begin{tabular}{ccccc}
\hline Variable & Coefficient & Std. Error & t-Statistic & Prob. \\
\hline DER & -0.420419 & 0.076152 & -5520790 & 0.0000 \\
ROA & -1842225 & 0.493358 & -3734054 & 0.0004 \\
SIZE & 0.009023 & 0.003463 & 2605791 & 0.0110 \\
INSTOW & 3034087 & 8047101 & 3770410 & 0.0003 \\
C & 0.300680 & 0.095655 & 3143383 & 0.0024 \\
\multicolumn{2}{c}{ R-squared } & & 0.373563 \\
& Adjusted R-squared & & 0.340153 \\
& F-statistic & & 11,18118 \\
\hline
\end{tabular}

Sumber: hasil output program Eviews 9.0, 2017

Tabel 3 menunjukkan hasil penelitian ini. Dalam penelitian ini, berdasarkan hasil uji regresi data panel variabel independen mampu menjelaskan variabel dependen sebesar 34,0153\%. Hal ini dilihat dari nilai Adjusted $R^{2}$ yang dihasilkan.

Berdasarkan hasil regresi, variabel leverage dengan proksi debt to equity ratio (DER) memiliki pengaruh negatif dan signifikan terhadap tax avoidance. Semakin tinggi nilai dari rasio leverage berarti semakin tinggi jumlah pendanaan dari utang pihak ketiga yang digunakan perusahaan dan semakin tinggi pula biaya bunga yang timbul. Dengan adanya biaya bunga yang semakin tinggi akan memberikan pengaruh berkurangnya laba sebelum pajak perusahaan, maka hal tersebut memberikan pengaruh terhadap beban pajak perusahaan yang semakin rendah. Sehingga penggunaan utang oleh perusahaan dapat digunakan untuk penghematan pajak dengan memperoleh insentif berupa beban bunga yang akan menjadi pengurang penghasilan kena pajak. sehingga pihak manajemen akan memanfaatkan pembiayaan yang berasal dari utang agar laba perusahaan akan semakin kecil karena adanya biaya bunga yang besar maka menimbulkan beban pajak perusahaan akan menjadi rendah. Hasil penelitian ini mendukung penelitian Calvin (2015) yang menyatakan bahwa leverage berpengaruh signifikan ke arah yang negatif terhadap CETR. 
Variabel profitability dengan proksi return on assets (ROA) memiliki pengaruh negatif dan signifikan. Hal ini berarti apabila ROA mengalami peningkatan maka cash effective tax rate semakin rendah, CETR yang rendah mengindikasikan tingginya aktivitas tax avoidance. Hal tersebut terjadi karena pajak dengan laba perusahaan berbanding lurus, apabila profitability perusahaan meningkat mengindikasikan semakin baiknya kinerja perusahaan dan semakin besar pula laba yang dihasilkan perusahaan maka hal tersebut mempengaruhi adanya beban pajak yang semakin tinggi. Hasil penelitian ini serupa dengan hasil penelitian Winoto dan Indarti (2015) serta Sari dan Kurniasih (2013) dan yang mendapatkan hasil bahwa profitability yang diproksikan dengan return on assets berpengaruh negatif terhadap cash effective tax rate (CETR).

Variabel ukuran perusahaan yang diproksikan dengan logaritma natural dari total aset perusahaan menunjukkan hasil berpengaruh postif terhadap cash effective tax rate (CETR). Semakin besar ukuran perusahaan maka semakin besar CETR pada perusahaan yang berarti menurunnya tingkat penghindaran pajak. Perusahaan yang termasuk dalam skala perusahaan besar akan mempunyai sumber daya yang berlimpah yang dapat digunakan untuk tujuan-tujuan tertentu. Hasil penelitian ini serupa dengan hasil penelitian Budiman \& setiyono (2012), Adelina (2012) dan Teguh (2015) yang menyatakan bahwa ukuran perusahaan berpengaruh positif dan signifikan terhadap CETR.

Variabel proporsi kepemilikan institusional yang diproksikan dengan INSTOW, indikator persentase jumlah saham yang dimiliki insitusi dari seluruh modal saham yang beredar di perusahaan menunjukkan hasil berpengaruh postif terhadap cash effective tax rate (CETR). Semakin tinggi kepemilikan institusional, maka semakin tinggi pula jumlah beban pajak yang harus dibayarkan oleh perusahaan.Hal ini dikarenakan semakin kecil kemungkinan praktik penghindaran pajak yang dilakukan oleh perusahaan. Pemilik institusional berdasarkan besar dan hak suara yang dimiliki, dapat memaksa manajer untuk berfokus pada kinerja ekonomi dan menghindari peluang untuk perilaku mementingkan diri sendiri. Hasil penelitian ini mendukung hasil penelitian yang dilakukan oleh Pranata, Puspa, dan Herawati (2013) serta Puspitasari dan Ngadiman (2014) yang menyatakan bahwa variabel kepemilikan institusional memiliki pengaruh yang positif dan signifikan terhadap tax avoidance.

\section{Implikasi Manajerial}

Hasil penelitian menyatakan bahwa leverage memiliki pengaruh negatif dan signifikan terhadap tingkat penghindaran pajak yang diproksikan dengan cash effective tax rate (CETR). Pihak manajemen memiliki pengaruh terhadap tingkat leverage perusahaan sehingga dapat meminimalkan pajak perusahaan dengan adanya perencanaan pajak (tax planning). Pihak agent akan cenderung menggunakan pendanaan dengan utang agar mengurangi laba perusahaan yang dikarenakan timbulnya insentif atas biaya bunga, sehingga akan mengurangi laba sebelum pajak perusahaan dan berarti pajak yang ditanggung akan semakin kecil. Hal tersebut merupakan perencanaan pajak untuk mengurangi jumlah beban kewajiban pajak. Dalam hal ini perusahaan dapat melakukan berbagai macam cara salah satunya adalah menerbitkan obligasi perusahaan untuk pembiayaan aktivitas operasional perusahaan.

Hasil penelitian untuk variabel independen profitability yang diproksikan dengan return on assets menunjukkan hasil berpengaruh negatif terhadap cash effective tax rate (CETR). Dalam pernyataan seperti ini maka perusahaan dengan profitability yang tinggi akan memiliki tax avoidance yang diproksikan dengan cash effective tax rate (CETR) yang rendah. CETR yang rendah tersebut meyebabkan perusahaan tersebut agresif terhadap penghindaran pajaknya karena perusahaan dengan profitabilitas yang tinggi akan melakukan usaha untuk 
meminimalkan pajak yang dibayarkan dengan cara perencanaan pajak perusahaan. Dengan adanya self assessment system di Indonesia Direktorat Jendral Pajak perlu memantau apakah perencanaan pajak yang dilakukan masih dalam batasan undangundang perpajakan atau sudah melanggar ketentuan undang-undang, maka perlu untuk menambahkan auditor pajak dan account representative pajak agar pengawasan pembayaran pajak perusahaan-perusahaan lebih optimal.

Dari hasil penelitian menemukan bahwa ukuran perusahaan (size) berpengaruh positif dan signifikan terhadap penghindaran pajak. Hal ini menunjukkan bahwa semakin besar ukuran perusahaan tersebut maka cash effective tax rate perusahaan akan semakin tinggi sehingga turunnya tingkaat penghindaran pajak. Hal ini mengindikasikan perusahaan besar akan menjadi sorotan pemerintah maka perusahaan besar akan menjaga reputasi perusahaan agar tetap baik di mata publik dan pemerintah dengan melakukan perencanaan pajak yang tidak melanggar ketentuan undang-undang perpajakan. Dalam hal ini Dierektorat Jendral Pajak perlu menambah account representative dan auditor pajak untuk memantau kegiatankegiatan usaha kecil yang kurang menjadi sorotan pemerintah.

Variabel independen terakhir dalam penelitian ini, proporsi kepemilikan institusional menunjukkan hasil bahwa memberikan pengaruh positif dan signifikan terhadap tax avoidance yang diproksikan dengan cash effective tax rate. Hal ini dapat disebabkan baik besar atau kecil persentase kepemilikan saham dapat mempengaruhi kebijakan yang diambil. Kepemilikan institusional memainkan peran penting dalam memantau, mendisiplinkan dan mempengaruhi keputusan manajemen. Hal ini juga dibuktikan bahwa semakin tinggi kepemilikan institusional, maka semakin tinggi pula jumlah beban pajak yang harus dibayarkan oleh perusahaan. Hal ini dikarenakan semakin kecil kemungkinan praktik penghindaran pajak yang dilakukan oleh perusahaan. Pemilik institusional berdasarkan besar dan hak suara yang dimiliki, dapat memaksa manajer untuk berfokus pada kinerja ekonomi dan menghindari peluang untuk perilaku mementingkan diri sendiri.

\section{Penutup}

Hasil ini menunjukkan bahwa leverage dan profitability memiliki pengaruh negatif dan signifikan terhadap tax avoidance karena perusahaan-perusahaan manufaktur sub sektor konsumsi merupakan perusahaan yang operasionalnya banyak dibiayai oleh hutang. Semakin besar utang maka laba kena pajak akan menjadi lebih kecil karena insentif pajak atas bunga utang yang semakin besar. Biaya bunga yang tinggi memberikan pengaruh berkurangnya beban pajak perusahaan. Oleh karena itu, semakin tinggi rasio leverage, maka semakin rendah CETR perusahaan sehinga mengindikasikan semakin tinggi penghindaran pajak yang dilakukan perusahaan. Laba perusahaan manufaktur sub sektor konsumsi relatif besar, yang artinya perusahaan dengan tingkat profitabilitas yang tinggi maka cash effective tax rate semakin rendah atau mengindikasikan semakin tinggi aktivitas penghindaran pajak perusahaan. Selain itu, hasil penelitian ini juga membuktikan bahwa ukuran perusahaan dan proporsi kepemilikan berpengaruh positif dan signifikan. Semakin besar ukuran perusahaan maka cash effective tax rate perusahaan akan semakin besar yang mengindikasikan tingkat penghindaran pajak yang semakin rendah. Hal ini juga menunjukkan bahwa semakin besar proporsi kepemilikan institusional maka akan semakin tinggi cash effective tax rate (CETR) pada perusahaan yang mengindikasikan semakin rendahnya tingkat penghindaran pajak yang dilakukan perusahaan.

Adapun dalam menyusun penelitian ini masih sangat banyak keterbatasan. Oleh karena keterbatasan itu, sehingga diharapkan untuk penelitian selanjutnya memperhatikan hal-hal berikut yang menjadi saran bagi peneliti selanjutnya: 
1. Penelitian ini hanya menggunakan perusahaan manufaktur sub sektor konsumsi yang terdaftar di Bursa Efek Indonesia (BEI), penelitian selanjutnya dapat menggunakan sampel seluruh perusahaan manufaktur yang terdaftar di Bursa Efek Indonesia (BEI).

2. Bagi penelitian selanjutnya diharapkan dapat menambah variabel lainnya, karena penelitian ini hanya memiliki adjusted $\mathrm{R}^{2}$ sebesar 34,0153\% maka masih banyak faktor yang dapat berkontribusi dalam mempengaruhi penghindaran pajak yang belum diteliti seperti resiko perusahaan, corporate governance, likuiditas, financial distress, sales growth, kompensasi rugi fiskal, dan sebagainya.

\section{Daftar Pustaka}

Annisa, N. A., \& Kurniasih, L. (2012). Pengaruh Corporate Governance Terhadap Tax Avoidance. Jurnal Akuntansi Dan Auditing, 8, 95-189.

Derashid, C., \& Zhang, H. 2003. Effective tax rates and the industrial policy hypothesis : evidence from Malaysia. Dalam Journal of International Accounting, Auditing and Taxation, :pp:45-62.

Diantari, P. R., \& Ulupui, I. A. (2016). Pengaruh Komite audit, Proporsi Komisaris Independen, dan Proporsi kepemilikan Institusional terhadap Tax Avoidance, 16, 702-732

Fahmi, Irfan. 2012. Analisis Kinerja Keuangan. Bandung: Alfabeta.

Jensen, M. and Meckling, 1976. Theory of The Firm: Managerial Behavior Agency Cost, and Ownership Structure. Journal of Finance Economic 3, 305-360.

Keuangan, D. S. A. (2009). Standar Akuntansi Keuangan Entitas Tanpa Akuntabilitas Publik. IAI. Jakarta.

Kurniasih, T., \& Sari, M. M. R. (2013). Pengaruh Return on Assets , Leverage , Corporate Governance, Ukuran Perusahaan Dan Kompensasi Rugi Fiskal Pada Tax Avoidance. Buletin Studi Ekonomi,18(1), 58-66.

Pohan, H. T. 2008. Pengaruh Good Corporate Governance, Rasio Tobin's q, Perata Laba terhadap Penghindaran Pajak pada Perusahaan Publik.

Pohan, Hotman T. 2009. Analisis Pengaruh Kepemilikan Institusi, Rasio Tobin Q,Akrual Pilihan, Tarif Efektif Pajak, Dan Biaya Pajak DitundaTerhadap Penghindaran Pajak Pada Perusahaan Publik. Jurnal Informasi, Perpajakan, Akuntansi Dan Keuangan Publik. Vol. 4, No. 2, Juli 2009Hal. 113 - 135.

Rego, S. O. (2003). Tax-avoidance activities of US multinational corporations. Contemporary Accounting Research, 20(4), 805-833.

Sabli, N., \& Noor M. R. (2012). Tax Planning and Corporate Governance. Proceeding International Conference on Business and Economic Research Bandung. ISBN: 978967-5705-05-2.

Siregar, S. V., \& Utama, S. (2005). Pengaruh Struktur Kepemilikan. Ukuran Perusahaan.

Sjahrial, D., \& Purba, D. (2011). Analisa Laporan Keuangan: Cara Mudah Dan Praktis Memahami Laporan Keuangan. Mitra Wacana Media. Jakarta.

Sudarmaji, A. M., \& Sularto, L. (2007). Pengaruh Ukuran Perusahaan, Profitabilitas dan Tipe Kepemilikan Perusahaan Terhadap Luas Voluntary Disclosure Laporan Keuangan 
Tahunan. Proceeding PESAT. Agustus, 63-61.

Verinoca, S., \& Utama, S. (2005). SNA VIII Solo, 15 - 16 September 2005. Simposium Nasional Akuntansi XVI, (September), 15-16.

Widyaningdyah, Agnes. (2001). Analisis Faktor-Faktor Yang Berpengaruh Terhadap Earning Management Pada Perusahan Go Public di Indonesia, Jurnal Ekonomi Akuntansi, Fakultas Ekonomi Universitas Kristen Petra. 